Biogeosciences Discuss., 7, 7207-7225, 2010

www.biogeosciences-discuss.net/7/7207/2010/

doi:10.5194/bgd-7-7207-2010

(C) Author(s) 2010. CC Attribution 3.0 License.

\title{
Methane production, consumption and its carbon isotope ratios in the Southern Ocean during the austral summer
}

\section{N. Boontanon ${ }^{1,2}$, S. Watanabe ${ }^{3}$, T. Odate $^{4}$, and N. Yoshida ${ }^{2,5}$}

${ }^{1}$ Faculty of Environment and Resource Studies, Mahidol University, 999 Phuttamonthon 4 Rd., Salaya, Phuttamonthon, Nakhon Pathom, 73170, Thailand

${ }^{2}$ SORST project, Japan Science and Technology Agency, 4-1-8 Honcho, Kawaguchi-shi, Saitama, 332-0012, Japan

${ }^{3}$ Japan Marine Science and Technology Center, 2-15 Natsushima-Cho, Yokosuka, Kanagawa, 237-0061, Japan

${ }^{4}$ National Institute of Polar Research, Kaga 1-chome, Itabashi-ku, Tokyo, 173-8515, Japan ${ }^{5}$ Department of Environmental Science and Technology, Interdisciplinary Graduate School of Science and Engineering, Tokyo Institute of Technology, 4259-G5-4 Nagatsuta, Midori-ku, Yokohama, 226-8502, Japan
Methane production and consumption in the Southern Ocean

N. Boontanon et al.

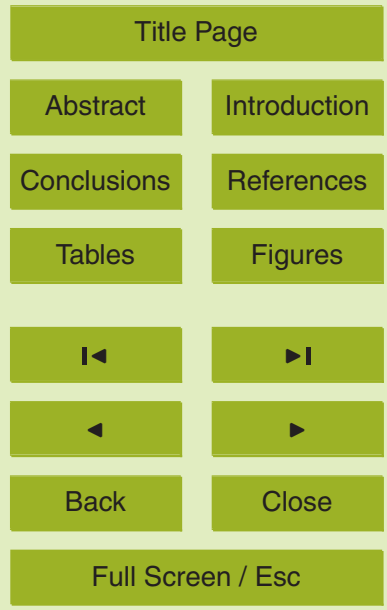

Printer-friendly Version

Interactive Discussion 
Received: 2 September 2010 - Accepted: 11 September 2010

- Published: 29 September 2010

Correspondence to: N. Boontanon (ennbt@mahidol.ac.th)

Published by Copernicus Publications on behalf of the European Geosciences Union.
BGD

$7,7207-7225,2010$

\section{Methane production and consumption in the Southern Ocean}

N. Boontanon et al.

Title Page

Abstract

Introduction

Conclusions

References

Tables

Figures

14

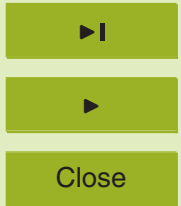

Back

Full Screen / Esc

Printer-friendly Version

Interactive Discussion 


\section{Abstract}

The distribution of dissolved $\mathrm{CH}_{4}$ in the Southern Ocean at $140^{\circ} \mathrm{E}$ was measured during the austral summer. Surface $\mathrm{CH}_{4}$ was supersaturated on average, and the calculated mean sea-air flux rate was $0.32 \mu \mathrm{mol} \mathrm{m}^{-2} \mathrm{~d}^{-1}$. The vertical distributions exhibited $5 \mathrm{a} \mathrm{CH}_{4}$ maximum at approximately $125 \mathrm{~m}\left(\Delta \mathrm{CH}_{4}, 2.94 \mathrm{nM}\right)$ below the chlorophyll-rich layer, suggesting a relationship between $\mathrm{CH}_{4}$ production and plankton dynamics in this area. $\mathrm{CH}_{4}$ oxidation and ocean movement characteristics in the deep layer led to the enrichment and fluctuation of $\delta^{13} \mathrm{C}_{\mathrm{CH}_{4}}$. We estimated the influence of Southern Ocean $\mathrm{CH}_{4}$, a source of isotopically heavy $\mathrm{CH}_{4}$ to the atmosphere, on the global $\mathrm{CH}_{4}$ budget to be approximately $0.19 \mathrm{Gg} \mathrm{d}^{-1}$.

\section{Introduction}

Considerable attention has recently been focused on biogenic trace gases in ecosystems because they include a significant amount of greenhouse gases. Methane $\left(\mathrm{CH}_{4}\right)$ is an effective greenhouse gas that is approximately 20 times more effective in radiative forcing than $\mathrm{CO}_{2}$ on a per mole basis and contributes significantly to global warming (Schneider, 1989). The atmospheric concentration of $\mathrm{CH}_{4}$ is currently increasing faster than that of other biogenic greenhouse gases (Pearman and Fraser, 1988; Bouwman, 1990). Each year, 50 million tons of $\mathrm{CH}_{4}$ are added to the atmosphere, resulting in a relative annual increase of more than 1\% (Bouwman, 1990). The primary sources of $\mathrm{CH}_{4}$ include wetlands, paddy fields, intestinal fermentation, and pyrolysis of organic matter, i.e., biomass burning (Cicerone and Oremland, 1988). However, methane produced in marine environments also contributes to atmospheric greenhouse gas concentrations and organic carbon cycle pathways. Furthermore, the isotopic signature of $\mathrm{CH}_{4}$ is recognized as providing constraints on relative source strength and information on

BGD

7, 7207-7225, 2010

\section{Methane production and consumption in the Southern Ocean}

N. Boontanon et al.

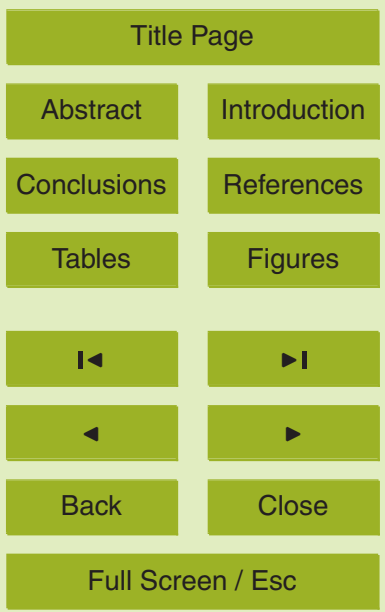

Printer-friendly Version

Interactive Discussion 
The Southern Ocean, one of the most productive water bodies in the world, has some characteristics unique among the world's oceans, i.e., the near-circular symmetry of most of its physical and chemical characteristics; the immense expanse of cold surface water, which is globally by far the largest; and the most pronounced seasonal variation 5 in sea surface temperature of any comparable ocean basin (Lutjeharms, 1990). The temporal and spatial distribution of these physical and chemical variables should also be reflected in the distribution patterns of biological processes. Here we describe the results of isotopic studies of dissolved $\mathrm{CH}_{4}$ in the Southern Ocean at $140^{\circ} \mathrm{E}$ to elucidate the origins of $\mathrm{CH}_{4}$ in the ocean and to estimate its $\mathrm{CH}_{4}$ contribution to the atmosphere.

\section{Materials and methods}

\subsection{Study sites and sampling}

Samples were collected during the 43rd Japanese Antarctic Research Expedition (JARE-43), 2002 Marine Science Cruise on the R/V Tangaroa from 6 February to 7 March 2002. The purpose of the expedition was to study the biogeochemical cycles 15 and biological processes of the Southern Ocean as they relate to global environmental issues. The production and consumption of dissolved $\mathrm{CH}_{4}$ in Southern Ocean ecosystems were investigated by collecting seawater samples at stations 1 (open water), 5 (marginal ice zone), and 8 (previous ice zone; Fig. 1). Water samples were collected at the indicated depths using a CTD water sampler (SBE 32 24×10-L Carousel Water ilized with mercury chloride ( $1 \mathrm{ml}$ of saturated $\mathrm{HgCl}_{2}$ solution per vial). The vials were then sealed with a butyl-rubber septum and an aluminum cap, taking care to avoid bubble formation, and stored at $4{ }^{\circ} \mathrm{C}$ in the laboratory until analysis.

\section{BGD}

$7,7207-7225,2010$

\section{Methane production and consumption in the Southern Ocean}

N. Boontanon et al.

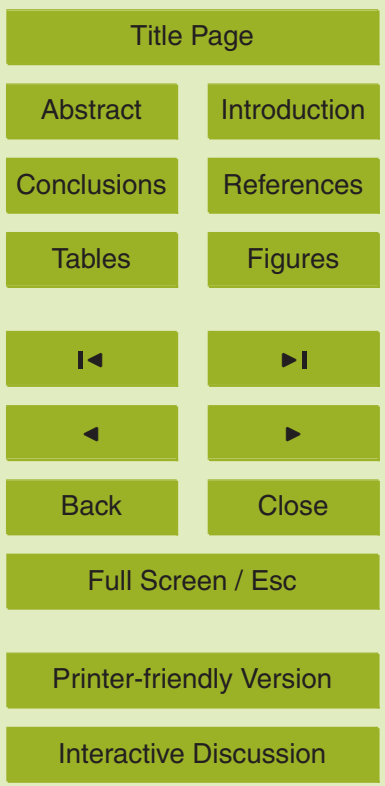




\subsection{Chemical analysis}

Salinity and temperature were recorded using a CTD sampler (SBE 911plus). Dissolved oxygen was measured with a dissolved oxygen auto-titrator based on the Scripps Institute of Oceanography design.

\subsection{Dissolved $\mathrm{CH}_{4}$ and carbon isotope analysis}

In the laboratory, water samples were transferred to a stripping chamber using helium gas replacement in the sample vials. After $\mathrm{H}_{2} \mathrm{O}$ and $\mathrm{CO}_{2}$ were removed in a magnesium perchlorate $\left[\mathrm{Mg}\left(\mathrm{ClO}_{4}\right)_{2}\right]$ and Ascarite (sodium hydroxide-coated silica) column, $\mathrm{CH}_{4}$ was collected in a U-shaped tube filled with activated charcoal (AC1) at liquid ni10 trogen temperature. At the end of the quantitative extraction of $\mathrm{CH}_{4}$, the $\mathrm{U}$-tube was heated to room temperature $\left(25^{\circ} \mathrm{C}\right)$ by removing a liquid nitrogen trap. The desorbed gas from the AC1 was separated in a molecular sieve column. The purified $\mathrm{CH}_{4}$ fraction was collected again in an activated charcoal (AC2) tube at liquid nitrogen temperature. The AC2 was then heated to room temperature by removal of the liquid nitrogen. The 15 desorbed $\mathrm{CH}_{4}$ was cryofocused before being introduced into the system $\mathrm{GC}$ and then separated in a PoraPlot $Q$ column $(25 \mathrm{~m})$ at $30^{\circ} \mathrm{C}$. The $\mathrm{GC}$ was connected to a combustion furnace made of quartz $(0.6 \mathrm{~mm} \times 15 \mathrm{~cm})$ filled with $\mathrm{CuO}$ at $960^{\circ} \mathrm{C}$. Methane was then combusted into $\mathrm{CO}_{2}$ and $\mathrm{H}_{2} \mathrm{O}$, and the produced $\mathrm{H}_{2} \mathrm{O}$ was removed by diffusion through a Nafion membrane tube. He-carrier gas was then partially separated using

20 a helium separator, and $\mathrm{CO}_{2}$ was introduced into the isotope ratio mass spectrometer (Finnigan, MAT 252). The carbon isotopic composition results were expressed as $\delta^{13} \mathrm{C}$ values, defined as:

$\delta^{13} \mathrm{C}(\%)=\left[\left(R_{\text {SAMPLE }} / R_{\text {STANDARD }}\right)-1\right] \times 1000$,

where $R_{\text {SAMPLE }}$ and $R_{\text {STANDARD }}$ are the isotope ratios $\left({ }^{13} \mathrm{C} /{ }^{12} \mathrm{C}\right)$ for samples and standards, respectively. Carbon isotope ratios of dissolved $\mathrm{CH}_{4}$ were expressed in \%。 deviations from PeeDee belemnite (PDB) carbonate. The $\delta{ }^{13} \mathrm{C}$ values were reproducible

BGD

$7,7207-7225,2010$

Methane production and consumption in the Southern Ocean

N. Boontanon et al.

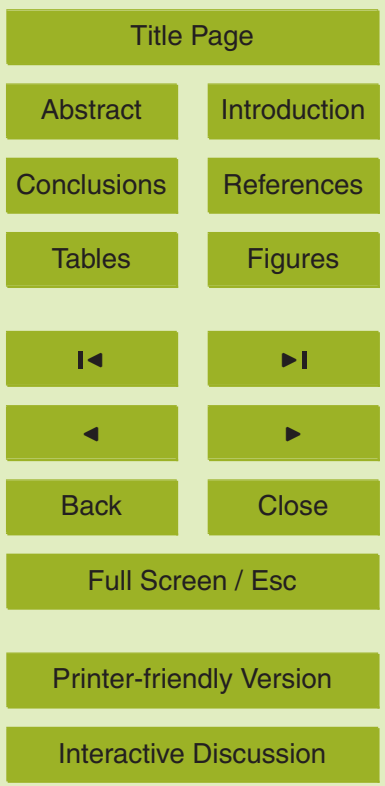

Interactive Discussion 
to within $\pm 0.3 \%$. The atmospheric equilibrium concentration of $\mathrm{CH}_{4}$ was calculated from in situ water temperatures and the atmospheric mixing ratio (1.7 ppmv; Quay et al., 1991; Holmes et al., 2000) following the methods of Yamamoto et al. (1976).

BGD

$7,7207-7225,2010$

\section{Methane production and consumption in the Southern Ocean}

N. Boontanon et al.

$$
\text { were related to physical and biological properties in the area. } \mathrm{CH}_{4} \text { concentrations and }
$$
$\delta^{13} \mathrm{C}$ values of the dissolved $\mathrm{CH}_{4}$ in surface water were almost in equilibrium with the atmosphere, with mean excess $\mathrm{CH}_{4}\left(\Delta \mathrm{CH}_{4}\right)$ and $\delta^{13} \mathrm{C}$ at $0.06 \mathrm{nM}$ (or $102 \%$ saturation) 10 and $-46.3 \%$, respectively. The $\Delta \mathrm{CH}_{4}$ maximum (2.94 $\mathrm{nM}$ or about $200 \%$ saturation) was observed in the subsurface (at a depth of approximately $125 \mathrm{~m}$ ) and decreased to a constant value below $1000 \mathrm{~m}$ at station 1 . The $\delta^{13} \mathrm{C}$ value at this station was generally enriched below $200 \mathrm{~m}$, in contrast to the $\mathrm{CH}_{4}$ concentration. However, small enrichments in $\delta^{13} \mathrm{C}$ were also observed in the $\mathrm{CH}_{4}$ maximum layer. While $\mathrm{CH}_{4}$ at sta15 tion 5 exhibited no subsurface maximum, the $\mathrm{CH}_{4}$ concentration gradually decreased with increased $\delta^{13} \mathrm{C}$ from the surface and reached a constant value below $500 \mathrm{~m}$. At station 8 , the $\mathrm{CH}_{4}$ concentration and $\delta{ }^{13} \mathrm{C}$ value remained close to atmospheric equilibrium from the surface to the deep region.

As $\mathrm{CH}_{4}$ is produced and/or oxidized by bacteria and also lost to the atmosphere 20 through gas exchange, the shape of a vertical profile must be determined by the balance between in situ biological production and consumption and physical processes of diffusion, advection, and gas exchange. Thus, dissolved $\mathrm{CH}_{4}$ and its isotope ratio could be categorized into three parts: surface, subsurface (including the $\mathrm{CH}_{4}$ maximum), and deeper regions.

25 At the surface where gas exchange occurs, the $\mathrm{CH}_{4}$ concentration is governed by physical factors, mainly temperature and wind, with gas saturation values up to about

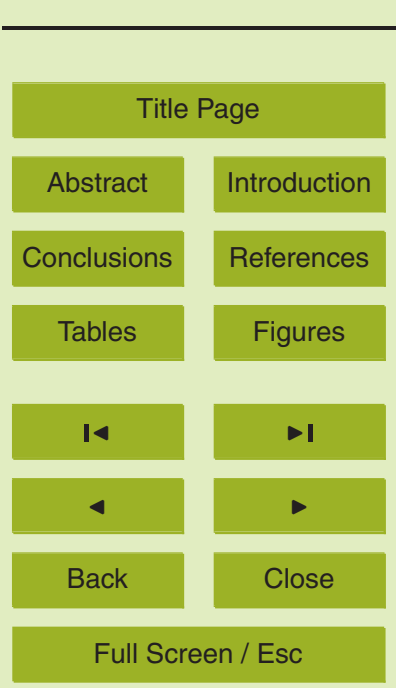

Printer-friendly Version

Interactive Discussion 
$5 \%$ above or below saturation (Bieri et al., 1966, 1968). The surface equilibrium of $\mathrm{CH}_{4}$ in the Southern Ocean could be caused by high wind speeds, given that temperatures in the area are quite stable during the austral summer. The $\delta^{13} \mathrm{C}$ values of surface dissolved $\mathrm{CH}_{4}$ at all stations were enriched by $0.2-1.2 \%$ o relative to the atmospheric 5 value (-47 to $-47.4 \%$; Holmes et al., 2000; Stevens, 1993), possibly because of the kinetic fractionation factors during $\mathrm{CH}_{4}$ invasion and evasion. Fuex (1980) found that the equilibrium fractionation $\left(\alpha_{\text {eq }}\right)$ for methane was about 1.00033, a value similar to our result and those observed in other areas (e.g., Holmes et al., 2000; Tsunogai et al., 2000; Valentine et al., 2001). The $\delta^{13} \mathrm{C}$ of dissolved $\mathrm{CH}_{4}$, however, was enriched 10 by more than $1 \%$, a value greater than can be attributed to analytical error at station 1 where wind speeds were high and were expected to result in a high $\mathrm{CH}_{4}$ exchange rate with surface water. This result suggests that the exchange of $\mathrm{CH}_{4}$ between ocean and atmosphere and its isotopic fractionation should be treated kinetically and considered temporally and spatially variable, as well as related to high in situ $\delta^{13} \mathrm{C}\left(\mathrm{CH}_{4}\right)$, even at 15 the surface.

Given that the microbial production of $\mathrm{CH}_{4}$ cannot occur in an oxic environment (Wolfe, 1971), it is thought that $\mathrm{CH}_{4}$ forms mostly within the reducing interiors of particles, as supported by incubation experiments (Karl and Tilbrook, 1994; Marty et al., 1997; Owens et al., 1991). In the Southern Ocean waters surrounding Antarctica, phytoplankton blooms fueled by nutrient-rich waters lead to the growth of vast swarms of krill (Euphausia superba) each summer. Consequently, settling particles, such as fecal pellets, may be produced during the life cycle of the krill, either directly or indirectly. Chlorophyll-a is the most important phytopigment and can be used as a semiquantitative measure of phytoplankton abundance. Hirawake et al. (2003) reported that chlorophyll-a concentrations show clear seasonal variation with a complicated spatial distribution; concentrations were very low $\left(<0.3 \mathrm{mg} \mathrm{m}^{-3}\right)$ in October, but rapidly increased to $1-5 \mathrm{mg} \mathrm{m}^{-3}$ through December near the sea-ice edge and in the open ocean. Furthermore, these particles do not consist only of inorganic or dead organic matter; they also host microbial communities, including bacteria, various protozoa, and

BGD

$7,7207-7225,2010$

\section{Methane production and consumption in the Southern Ocean}

N. Boontanon et al.

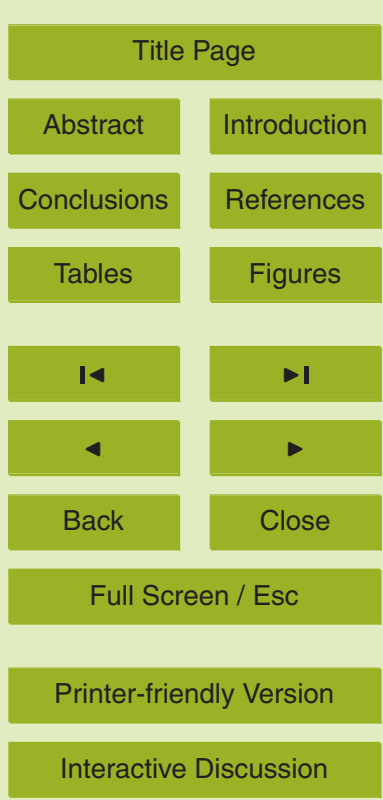


algal cells (Fenchel et al., 2000). Therefore, such particles could be expected to include anoxic microsites with active $\mathrm{CH}_{4}$ production (Alldredge and Cohen, 1987; Kiene, 1991; Sieburth, 1987). Biogenic $\mathrm{CH}_{4}$ is known to be produced via microbial methanogenesis. Major substrates for methanogenic bacteria include acetate and $\mathrm{CO}_{2} / \mathrm{H}_{2}$ (Cicerone and 5 Oremland, 1988; Whiticar et al., 1986). In the former substrate, $\mathrm{CH}_{4}$ is derived from the methyl group of acetate, and this process depends on the production of acetate at anaerobic sites during decomposition of organic matter. The carbon isotope fractionation factor for reduction of $\mathrm{CO}_{2}$ to $\mathrm{CH}_{4}$ has been reported for a pure culture system, and the high fractionation factor of 1.045 was reported for wetlands rich in labile organic 10 matter (Games et al., 1978). The general trend that governs the variation in $\delta^{13} \mathrm{C}$ of bacterial methane has been examined through paddy soil incubation experiments. The $\delta{ }^{13} \mathrm{C}$ value of $\mathrm{CH}_{4}$ from acetate was close to that of methyl carbon in acetate $(-43$ to $-30 \%$ ), while that from $\mathrm{CO}_{2} / \mathrm{H}_{2}$ reduction was -70 to $-60 \%$ (Sugimoto and Wada, 1993). The $\delta^{13} \mathrm{C}\left(\mathrm{CH}_{4}\right)$ value at the $\Delta \mathrm{CH}_{4}$ maximum, i.e., about $-43.4 \%$ at station 1 , 15 suggested that the formation of $\mathrm{CH}_{4}$ in this subsurface was produced via acetate fermentation. Blair and Carter (1992) reported the $\delta{ }^{13} \mathrm{C}$ value of acetate and estimated the $\delta^{13} \mathrm{C}$ of $\mathrm{CH}_{4}$ derived from acetate to be $-43 \%$ in anoxic marine sediment, which agrees well with our results. However, the large $\delta^{13} \mathrm{C}$ variation in settling organic matter in the Antarctic Ocean (-26.7 to $-20.5 \%$; Wada et al., 1987) may affect the $\delta^{13} \mathrm{C}$ of $\mathrm{CH}_{4}$ produced via acetate fermentation. The oxidation of the methyl position of acetate to $\mathrm{CO}_{2}$ may also cause the isotopic fractionation of the produced $\mathrm{CH}_{4}$ (Whiticar et al., 1986). However, the $\Delta \mathrm{CH}_{4}$ maximum peak was only observed at station 1, suggesting that the magnitude of $\mathrm{CH}_{4}$ production varied with abundance, distribution, and migration of phytoplankton and zooplankton in the area.

25 In the deeper subsurface waters, the $\Delta \mathrm{CH}_{4}$ value became negative in association with ${ }^{13} \mathrm{C}$ enrichment, suggesting the oxidation of dissolved $\mathrm{CH}_{4}$ with less or without new $\mathrm{CH}_{4}$ production. Thus, the residual, heavier $\delta^{13} \mathrm{C} \mathrm{CH}_{4}$ should be found based on the kinetic isotope effect during oxidation. Several researchers have demonstrated this process with aerobic culture systems and have found that the magnitude of carbon
BGD

$7,7207-7225,2010$

\section{Methane production and consumption in the Southern Ocean}

N. Boontanon et al.

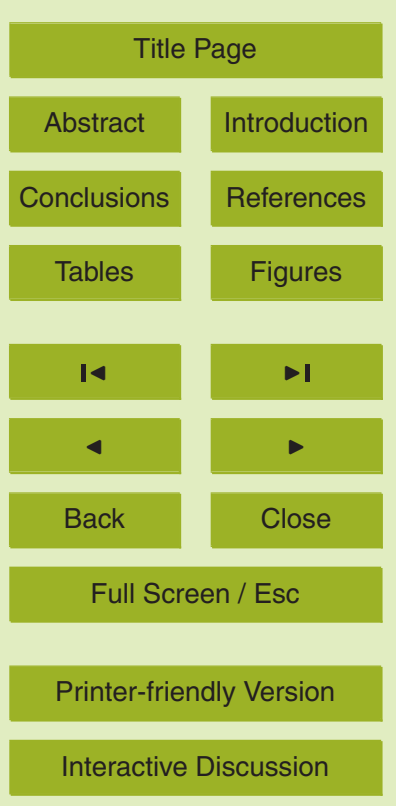


isotope fractionation varies from 5 to 31\% (e.g., Barker and Fritz, 1981; Zyakun et al., 1984). Such water column $\mathrm{CH}_{4}$ oxidation has also been observed in other areas, such as at the ALOHA station and in the North Atlantic (Holmes et al., 2000), suggesting that the oxidative consumption could occur normally in oxic water column environments. 5 Other parameters that could indicate $\mathrm{CH}_{4}$ oxidation include the preferential loss of $\mathrm{CH}_{4}$ relative to higher molecular weight hydrocarbons (Whiticar, 1999) and the systematic shift in $\mathrm{H}$ isotope ratios (Coleman et al., 1981; Whiticar, 1999). Furthermore, in deep water, at approximately $2500 \mathrm{~m}$, the horizontal and vertical movements of cold water from inshore induced by the geopotential anomaly of the strong steering of the cur10 rent by the ridge system around Antarctica (see Lutjeharms, 1990; Orsi et al., 1995) should affect the $\delta^{13} \mathrm{C}$ level of $\mathrm{CH}_{4}$. The $\Delta \mathrm{CH}_{4}$ values did not decrease below $500 \mathrm{~m}$ and $1000 \mathrm{~m}$ at stations 5 and 1 , respectively, probably because of the lack of $\mathrm{CH}_{4}$ consumption in deeper water (Scranton and Brewer, 1978). Also, the isotope ratio varies with depth because of the mixing of different water masses with different histories of $\mathrm{CH}_{4}$ input (Holmes et al., 2000). It should be noted that at station 8, located in a shallow water column close to shore, the strong steering of the summer current may promote vertical homogeneity of the $\mathrm{CH}_{4}$ concentrations and isotopic compositions.

The degassing of supersaturated surface seawater could release $\mathrm{CH}_{4}$ and sources of isotopically heavy $\mathrm{CH}_{4}$ into the earth's atmosphere by simple diffusion and thereby contribute to the net flux of $\mathrm{CH}_{4}$ across the sea-air interface. It is premature to quantitatively calculate the influence of the Southern Ocean on the global $\mathrm{CH}_{4}$ budget from the present data alone; however, our results do provide some insight into the contribution of the Southern Ocean. The estimated amount of $\mathrm{CH}_{4}$ that will eventually reach the atmosphere after transport through the unsaturated zone can be determined from the empirical relationship between wind speed and gas transfer rate with measured values for wind speed, temperature, and surface concentrations of $\mathrm{CH}_{4}$, according to the following equation (Liss and Slater, 1974):

$F=K_{\mathrm{L}}\left(C_{\mathrm{S}}-C_{\mathrm{E}}\right)$,

BGD

$7,7207-7225,2010$

Methane production and consumption in the Southern Ocean

N. Boontanon et al.

Title Page

Abstract

Introduction

Conclusions

Tables

References

Figures

14

$\rightarrow 1$

4

Back

Close

Printer-friendly Version

Interactive Discussion 
where $K_{\mathrm{L}}$ is the liquid-phase gas-transfer coefficient, $C_{\mathrm{S}}$ is the gas concentration in the surface water; and $C_{\mathrm{E}}$ is the gas concentration of the solution during equilibrium with the overlying gas phase. The liquid-phase gas-transfer coefficient, $K_{\mathrm{L}}$, used in calculating the flux was obtained from Liss and Merlivat (1986):

$5 K_{\mathrm{L}}=2.85 \mathrm{~V}-9.65\left(\mathrm{~cm} \mathrm{~h}^{-1}\right)$,

and Wanninkhof (1992):

$K_{\mathrm{L}}=0.31 \mathrm{~V}^{2}\left(\frac{S c}{660}\right)^{-1 / 2}\left(\mathrm{~cm} \mathrm{~h}^{-1}\right)$

where $V$ is wind velocity $\left(\mathrm{m} \mathrm{s}^{-1}\right)$, and $S c$ is the Schmidt number. The Schmidt number for $\mathrm{CH}_{4}$ in seawater is expressed as a decreasing function of temperature (Wanninkhof, 10 1992):

$S c_{\mathrm{CH}_{4}}=2039.2-120.31 T+3.4209 T^{2}-0.040437 T^{3}$

The calculated net sea-air flux of $\mathrm{CH}_{4}$ in the Southern Ocean is an average of $0.32 \mu \mathrm{mol} \mathrm{m}{ }^{-2} \mathrm{~d}^{-1}$ (-0.09 to $0.74 \mu \mathrm{mol} \mathrm{m}^{-2} \mathrm{~d}^{-1}$ ), using the Liss and Merlivat (1986) and Wanninkhof (1992) transfer coefficients. The $\Delta \mathrm{CH}_{4}$ maximum observed at the base of the mixed layer would result in a diffusive flux of $\mathrm{CH}_{4}$ into the surface layer. We also obtained $\delta^{13} \mathrm{C}$ of about $-41.8 \%$ ofor the source of $\mathrm{CH}_{4}$ formation from the isotopic correlation with the inverse concentration between the surface and the $\mathrm{CH}_{4}$ maximum and estimated the vertical net flux to be about $0.26 \mu \mathrm{mol} \mathrm{m}^{-2} \mathrm{~d}^{-1}$ from the one-dimensional vertical mixing coefficient ( $\mathrm{Li}$ et al., 1984) at station 1. This input accounted for about $80 \%$ of the estimated net flux of $\mathrm{CH}_{4}$ in the Southern Ocean to the atmosphere and suggested that $\mathrm{CH}_{4}$ was produced by in situ biological processes, diffused through the mixed layer, and then released by sea-air exchange. The consumption loss rate of $0.01 \mu \mathrm{mol} \mathrm{m}{ }^{-2} \mathrm{~d}^{-1}$, calculated from an average $\mathrm{CH}_{4}$ concentration in the upper $70 \mathrm{~m}$ and an average $\mathrm{CH}_{4}$ turnover time, was negligible compared to the losses associated
BGD

$7,7207-7225,2010$

\section{Methane production and consumption in the Southern Ocean \\ N. Boontanon et al.}

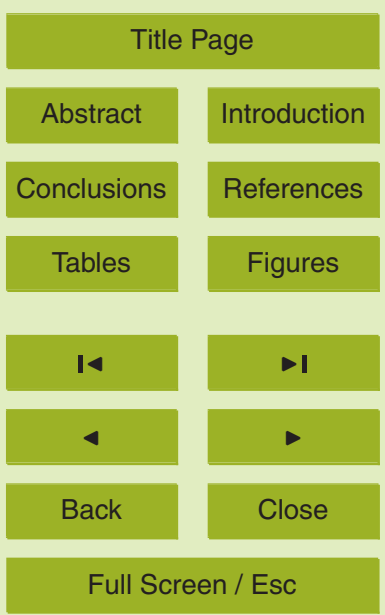

Printer-friendly Version

Interactive Discussion 
with sea-air exchange because of the long turnover time (an average of $65 \mathrm{yr}$; Jones, 1991; Ward et al., 1987). The $\mathrm{CH}_{4}$ flux in this area was much higher than that reported for Drake Passage and the Weddell Sea during the austral summer and autumn, respectively (Heeschen et al., 2004; Tilbrook and Karl, 1994); both locations showed 5 negative flux values (Table 1). However, positive flux values have been found in coastal areas with $\mathrm{CH}_{4}$ accumulation (Tilbrook and Karl, 1994). This could suggest that sea-air flux of $\mathrm{CH}_{4}$ varies greatly in time and space depending on physical factors as well as the magnitude of $\mathrm{CH}_{4}$ diffusion from the $\mathrm{CH}_{4}$ maximum layer. If this flux value could be applied to the entire Southern Ocean, which has an area of about $37 \times 10^{12} \mathrm{~m}^{2}$ (Peng, 10 1984), for the duration of the austral summer, the total $\mathrm{CH}_{4}$ flux to the atmosphere from this region would be $0.19 \mathrm{Gg} \mathrm{d}^{-1}$. The value of $\delta^{13} \mathrm{C}$ for the $\mathrm{CH}_{4}$ flux to the atmosphere was calculated using the following equation from Quay et al. (1993) and Hoefs (1987):

$\delta^{13} \mathrm{C}_{\mathrm{CH}_{4}}$ flux (\%o) $=\left\{\left[\frac{G \alpha_{k} \frac{\left(p \mathrm{CH}_{4[\mathrm{~atm}]} R_{\mathrm{atm}} \alpha_{\mathrm{sol}}-p \mathrm{CH}_{4[\mathrm{ml}]} R_{\mathrm{ml}}\right)}{G\left(p \mathrm{CH}_{4[\mathrm{~atm}]}-p \mathrm{CH}_{4[\mathrm{ml}]}\right)}}{R_{\mathrm{PDB}}}\right]-1\right\} \times 1000$,

where $R_{\text {atm }}$ is the ${ }^{13} \mathrm{C} /{ }^{12} \mathrm{C}$ ratio of atmospheric $\mathrm{CH}_{4}, R_{\mathrm{ml}}$ is the ${ }^{13} \mathrm{C} /{ }^{12} \mathrm{C}$ ratio of $\mathrm{CH}_{4}$ 15 in the mixed layer, $\alpha_{k}$ is 0.9992 (Knox et al., 1992; Happell et al., 1995), $\alpha_{\text {sol }}$ is 1.00033 (Fuex, 1980), $p \mathrm{CH}_{4}$ in the methane partial pressure, $\delta^{13} \mathrm{C}_{\mathrm{CH}_{4[\mathrm{~atm}]}}$ is -47.0 to $-47.4 \%$ (Quay et al., 1991; Holmes et al., 2000), and $R_{\mathrm{PDB}}$, the isotopic ratio of the PDB standard, is 0.011237 (Craig, 1957). We determined that the average $\delta^{13} \mathrm{C}$ value supplied to the atmosphere in the $\mathrm{CH}_{4}$ flux from this area was $-42.7 \%$ o (Table 1). This contribution (approx. $0.19 \mathrm{Gg} \mathrm{d}^{-1}$ ) is a significant part of the global oceanic $\mathrm{CH}_{4}$ flux of 5-50 Tg yr $^{-1}$ (2.4-24 $\mathrm{mmol} \mathrm{m}^{-2} \mathrm{~d}^{-1}$; Prather, 1995). Thus, the Southern Ocean could be contributing $0.14-1.39 \%$ of the total oceanic flux of $\mathrm{CH}_{4}$. However, if we consider other results from the circum-Antarctic region (Heeschen et al., 2004; Tilbrook and Karl, 1994), the total net sea-air $\mathrm{CH}_{4}$ flux from the Southern Ocean would be about

$0.15 \mathrm{Tg} \mathrm{yr}^{-1}$, equivalent to $0.30-3.0 \%$ of the total oceanic $\mathrm{CH}_{4}$ contribution. Moreover,

BGD

7, 7207-7225, 2010

\section{Methane production and consumption in the Southern Ocean}

N. Boontanon et al.

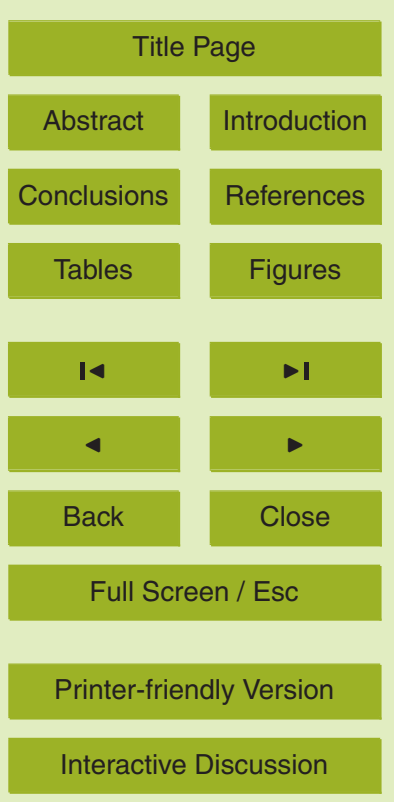

Interactive Discussion 
the $\delta^{13} \mathrm{C}_{\mathrm{CH}_{4}}$ flux could provide information concerning the isotopically heavy source also entering the atmosphere (-54.2\%。; Whiticar, 1993).

BGD

$7,7207-7225,2010$

\section{Conclusions}

The distribution of $\mathrm{CH}_{4}$ and its isotopic compositions in the Southern Ocean during 5 the austral summer suggest that surface water $\mathrm{CH}_{4}$ concentrations are controlled by physical factors and ocean water movement from glacial regions. A subsurface $\mathrm{CH}_{4}$ maximum was associated with the decomposition of sinking organic matter, suggesting a relationship between $\mathrm{CH}_{4}$ production and plankton dynamics in the area. $\mathrm{CH}_{4}$ oxidation and physical characteristics of water movements in the deep layer led to the enrichment and fluctuation of $\delta^{13} \mathrm{C}_{\mathrm{CH}_{4}}$. We estimated the influence of Southern Ocean $\mathrm{CH}_{4}$, a source of isotopically heavy $\mathrm{CH}_{4}$ to the atmosphere, on the global $\mathrm{CH}_{4}$ budget to be about $0.19 \mathrm{Gg} \mathrm{d}^{-1}$.

Acknowledgements. We would like to thank E. Wada and an anonymous reviewer for their constructive comments on the manuscript. We also thank the officers and crew of the R/V Tangaroa

\section{References}

Alldredge, A. L. and Cohen, Y.: Can microscale chemical patches persist in the sea? Microelectrode study of marine snow, fecal pellets, Science, 235, 689-691, 1987.

Barker, J. F. and Fritz, P.: Carbon isotope fractionation during microbial methane oxidation, Nature, 293, 289-291, 1981.

Bieri, R. H., Koide, M., and Goldberg, E. D.: The noble gas contents of Pacific sea waters, J. Geophys. Res., 71, 5243-5265, 1966.

Bieri, R. H., Koide, M., and Goldberg, E. D.: Noble gas contents of marine waters, Earth Planet. Sc. Lett., 4, 329-333, 1968.

Methane production and consumption in the Southern Ocean

N. Boontanon et al.

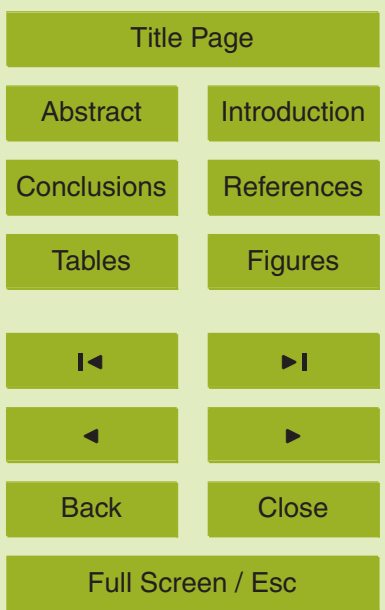

Printer-friendly Version

Interactive Discussion 
Blair, N. E. and Carter Jr., W. D.: The carbon isotope biogeochemistry of acetate from a methanogenic sediment, Geochim. Cosmochim. Acta, 56, 1247-1258, 1992.

Bouwman, A. F.: Exchange of greenhouse gases between terrestrial ecosystems and the atmosphere, in: Soil and greenhouse effect, edited by: Bouwman, A. F., John Wiley \& Sons, New York, 61-127, 1990.

Cicerone, R. J. and Oremland, R. S.: Biogeochemical aspects of atmospheric methane, Global Biogeochem. Cy., 2, 299-327, 1988.

Coleman, D. D., Risatti, J. B., and Schoell, M.: Fractionation of carbon and hydrogen isotopes by methane-oxidizing bacteria, Geochim. Cosmochim. Acta, 45, 1033-1037, 1981.

10 Conrad, R. and Seiler, M.: Methane and hydrogen in seawater, Deep-Sea Res., 35, 19031917, 1988.

Craig, H.: Isotopic standards for carbon and oxygen and correction factors for mass spectrometric analysis of carbon dioxide, Geochim. Cosmochim. Acta, 12, 133-149, 1957.

Ehhalt, D. H.: The atmospheric cycle of methane, Tellus, 26, 58-70, 1974.

Fenchel, T., King, G. M., and Blackburn, T. H.: Bacterial Biogeochemistry: the ecophysiology of mineral cycling, Academic Press, London, 2000.

Fuex, A. N.: Experimental evidence against an appreciable isotopic fractionation of methane during migration, Phys. Chem. Earth, 12, 725-732, 1980.

Games, L. M., Hayes, J. M., and Gunsalus, R. P.: Methane-producing bacteria: natural fractionations of the stable carbon isotopes, Geochim. Cosmochim. Acta, 42, 1295-1297, 1978.

Happell, J. D., Chanton, J. P., and Showers, W. J.: Methane transfer across the water-air interface in stagnant wooded swamps of Florida: Evaluation of mass-transfer coefficients and isotopic fractionation, Limnol. Oceanogr., 40, 290-298, 1995.

Heeschen, K. U., Keir, R. S., Rehder, G., Klatt, O., and Suess, E.: Methane dynamics in the Weddell Sea determined via stable isotope ratios and CFC-11, Global Biogeochem. Cy., 18, GB2012, doi:10.1029/2003GB002151, 2004.

Hirawake, T., Kudoh, S., Aoki, S., and Rintoul S. R.: Eddies revealed by SeaWiFS ocean color images in the Antarctic Divergence zone near $140^{\circ} \mathrm{E}$, Geophys. Res. Lett., 30, 1458, doi:10.1029/2003GL016996, 2003.

30 Hoefs, J.: Stable Isotope Geochemistry, Springer, New York, 1987.

Holmes, M. E., Sansone, F. J., Rust, T. M., and Popp, B. N.: Methane production, consumption, and air-sea exchange in the open ocean: An evaluation based on carbon isotopic ratios, Global Biogeochem. Cy., 14, 1-10, 2000.

\section{BGD}

$7,7207-7225,2010$

\section{Methane production and consumption in the Southern Ocean}

N. Boontanon et al.

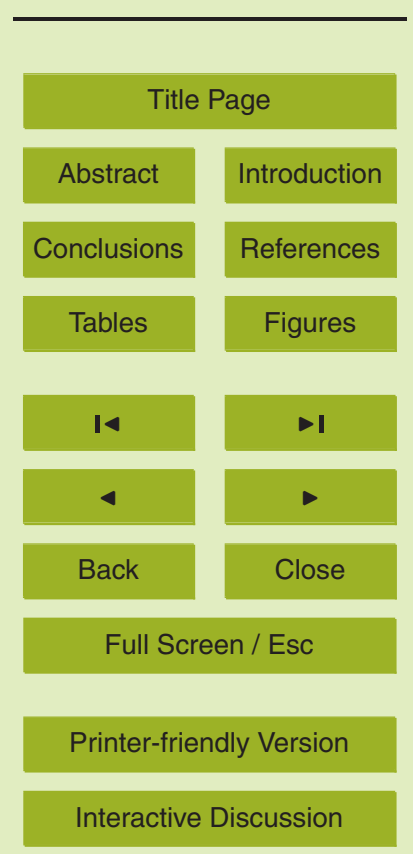


Jones, R. D.: Carbon monoxide and methane distribution and consumption in the photic zone of the Sargasso Sea, Deep-Sea Res., 38, 625-635, 1991.

Karl, D. M. and Tilbrook, B. D.: Production and transport of methane in oceanic particulate organic matter, Nature, 368, 732-734, 1994.

5 Kiene, R. P.: Production and consumption of methane in aquatic systems, in: Microbial production and consumption of greenhouse gases: methane, nitrogen oxides, and halomethanes, edited by: Rogers, J. E. and Whitman, W. E., American Society for Microbiology Press, Washington, DC, 111-146, 1991.

Knox, M., Quay, P. D., and Wilbur, D.: Kinetic isotopic fractionation during air-water gas transfer of $\mathrm{O}_{2}, \mathrm{~N}_{2}, \mathrm{CH}_{4}$ and $\mathrm{H}_{2}$, J. Geophys. Res., 97, 20335-20343, 1992.

Li, Y. H., Peng, T. H., Broecker, W. S., and Östlund, H. G.: The average vertical mixing coefficient for the oceanic thermocline, Tellus B, 36, 212-217, 1984.

Liss, P. S. and Slater, P. G.: Flux of gases across the air-sea interface, Nature, 247, 181-184, 1974.

15 Liss, P. S. and Merlivat, L.: Air-sea gas exchange rates: Introduction and synthesis, in: The role of air-sea exchange in geochemical cycling, edited by: Buat-Ménard, P., D. Reidel Pub. Co., Dordrecht, 113-127, 1986.

Lutjeharms, J. R. E.: The oceanography and fish distribution of the Southern Ocean, in: Fish of the Southern Ocean, edited by: Gon, O. and Heemstra, P. C., Smith J. L. B. Institute of Ichthyology, Grahamstown, 6-27, 1990.

Marty, D., Nival, P., and Yoon, W. D.: Methanoarchaea associated with sinking particles and zooplankton collected in the Northeastern tropical Atlantic, Oceanol. Acta, 20, 863-869, 1997.

Oris, A. H., Whitworth III, M., and Nowlin Jr., W. D.: On the meridional extent and fronts of the Antarctic Circumpolar Current, Deep-Sea Res. Pt. I, 42, 641-673, 1995.

Owens, N. J. P., Law, C. S., Mantoura, R. F. C., Burkill, P. H., and Llewellyn, C. A.: Methane flux to the atmosphere from the Arabian Sea, Nature, 354, 293-296, 1991.

Pearman, G. I. and Fraser, P. J.: Sources of increased methane, Nature, 332, 489-490, 1988.

Peng, T. H.: Invasion of fossil fuel $\mathrm{CO}_{2}$ into the ocean, in: Gas transfer at water surfaces, edited by: Brutsaert, W. and Jirka, G. H., D. Reidel Pub. Co., Dordrecht, 589-595, 1984.

Prather, M., Derwent, R., Ehhalt, D., Fraser, P., Sanhueza, E., and Zhou, X.: Other trace gases and atmospheric chemistry, in: Climate change 1994: relative forcing of climate change and an evaluation of the IPCC IS92 emission scenario, edited by: Houghton, J. T., Filho, L. G. M.,

BGD

$7,7207-7225,2010$

\section{Methane production and consumption in the Southern Ocean}

N. Boontanon et al.

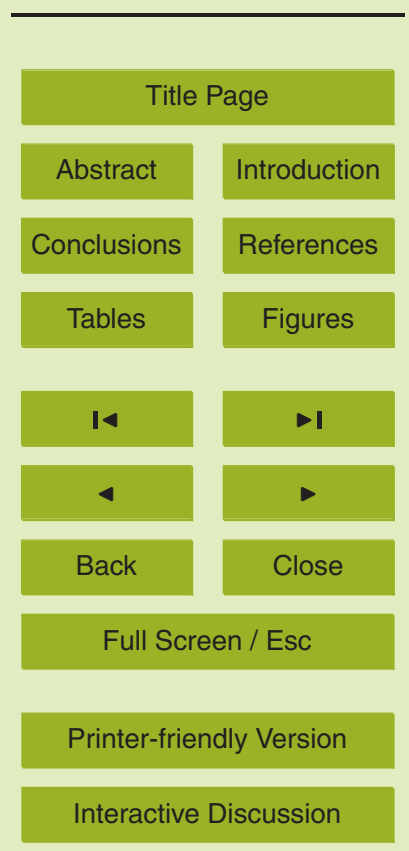

Interactive Discussion 
Bruce, J., Lee, H., Callander, B. A., Haites, E., and Maskell, K., Cambridge University Press, New York, 73-126, 1995.

Quay, P. D., King, S. L., Landsdown, J. M., and Wilbur, D. O.: Carbon isotopic composition of atmospheric $\mathrm{CH}_{4}$ : fossil and biomass burning source strengths, Global Biogeochem. Cy., 5, 5 25-47, 1991.

Quay, P. D., Emerson, S., Wilbur, D. O., Stump, C., and Knox, M.: The $\delta^{18} \mathrm{O}$ of dissolved $\mathrm{O}_{2}$ in the surface water of the subarctic Pacific: A tracer of biological activity, J. Geophys. Res., 98, 8447-8458, 1993.

Sansone, F. J., Popp, B. N., Gasc, A., Graham, A. W., and Rust, T. M.: Highly elevated methane in the eastern tropical North Pacific and associated isotopically enriched fluxes to the atmosphere, Geophys. Res. Lett., 28, 4567-4570, 2001.

Schneider, S. H.: The greenhouse effect: Science and policy, Science, 243, 771-781, 1989.

Scranton, M. I. and Brewer, P. G.: Consumption of dissolved methane in the deep ocean, Limnol. Oceanogr., 23, 1207-1213, 1978.

Sieburth, J. M. N.: Contrary habitats for redox-specific processes: Methanogenesis in oxic waters and oxidation in anoxic waters, in: Microbes in the sea, edited by: Sleigh, M. A., Harwood, New York, 11-38, 1987.

Stevens, C. M.: Isotopic abundances in the atmosphere and sources, in: Atmospheric methane: sources, sinks, and role in global change, edited by: Khalil, M. A. K., Springer, New York, 62-88, 1993.

Sugimoto, A. and Wada, E.: Carbon isotopic composition of bacterial methane in a soil incubation experiment: contribution of acetate and $\mathrm{CO}_{2} / \mathrm{H}_{2}$, Geochim. Cosmochim. Acta, 57, 4015-4027, 1993.

Swinnerton, J. W. and Lamontagne, R. A.: Oceanic distribution of low-molecular-weight hydrocarbons: Baseline measurements, Environ. Sci. Technol., 8, 657-663, 1974.

Tilbrook, E. D. and Karl, D. M.: Dissolved methane distributions, sources, and sinks in the western Bransfield Strait, Antarctica, J. Geophys. Res., 99, 16383-16393, 1994.

Tsunogai, U., Yoshida, N., Ishibashi, J., and Gamo, T.: Carbon isotopic distribution of methane in deep-sea hydrothermal plume, Myojin Knoll Caldera, Izu-Bonin arc: Implications for mi30 crobial methane oxidation in the oceans and applications to heat flux estimation, Geochim. Cosmochim. Acta, 64, 2439-2452, 2000.

\section{BGD}

$7,7207-7225,2010$

\section{Methane production and consumption in the Southern Ocean}

N. Boontanon et al.

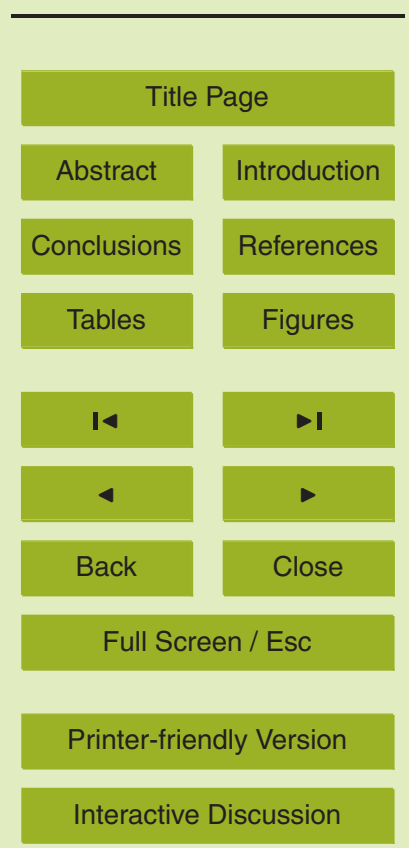


Valentine, D. L., Blanton, D. C., Reeburge, W. S., and Kastner, M.: Water column methane oxidation adjacent to an area of active hydrate dissociation, Eel River Basin, Geochim. Cosmochim. Acta, 65, 2633-2640, 2001.

Wada, E., Terazaki, M., Kabaya, Y., and Nemoto, T.: ${ }^{15} \mathrm{~N}$ and ${ }^{13} \mathrm{C}$ abundances in the Antarctic 5 Ocean with emphasis on the biogeochemical structure of the food web, Deep-Sea Res., 34, 829-841, 1987.

Wanninkhof, R.: Relationship between wind speed and gas exchange over the ocean, J. Geophys. Res., 97, 7373-7382, 1992.

Ward, B. B., Kilpatrick, K. A., Novelli, P. C., and Scranton, M. I.: Methane oxidation and methane fluxes in the ocean surface layer and deep anoxic waters, Nature, 327, 226-229, 1987.

Whiticar, M. J., Faber, E., and Schoell, M.: Biogenic methane formation in marine and freshwater environments: $\mathrm{CO}_{2}$ reduction vs. acetate fermentation-Isotope evidence, Geochim. Cosmochim. Acta, 50, 693-709, 1986.

Whiticar, M. J.: Stable isotopes and global budgets, in: Atmospheric methane: sources, sinks, 15 and role in global change, edited by: Khalil, M. A. K., Springer, New York, 138-167, 1993.

Whiticar, M. J.: Carbon and hydrogen isotope systematics of bacterial formation and oxidation of methane, Chem. Geol., 161, 291-314, 1999.

Wolfe, R. S.: Microbial formation of methane, Adv. Microb. Physiol., 6, 107-146, 1971.

Yamamoto, S., Alcauskad, J. B., and Crozier, T. E.: Solubility of methane in distilled water and seawater, J. Chem. Eng. Data, 21, 78-80, 1976.

Zyakun, A. M., Bondar, V. A., Namsarayev, B. B., and Nesterov, A. I.: Use of carbon-isotope analysis in determining the rates of microbiological oxidation of methane in natural ecosystems, Geochem. Int+., 22, 67-72, 1984.

\section{BGD}

7, 7207-7225, 2010

\section{Methane production and consumption in the Southern Ocean}

N. Boontanon et al.

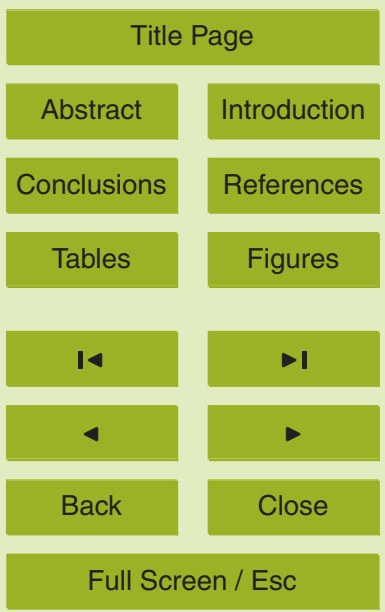

Printer-friendly Version

Interactive Discussion 
BGD

7, 7207-7225, 2010

\section{Methane production and consumption in the Southern Ocean}

Table 1. Methane concentrations and $\delta^{13} \mathrm{C}_{\mathrm{CH}_{4}}$ and fluxes to the atmosphere from the ocean surface. Numbers in parentheses indicate ranges in value.

\begin{tabular}{|c|c|c|c|c|c|}
\hline Location & $\begin{array}{l}\text { Mixed layer }\left[\mathrm{CH}_{4}\right] \\
(\mathrm{nM})\end{array}$ & $\begin{array}{l}\text { Mixed layer } \delta^{13} \mathrm{C}_{\mathrm{CH}_{4}} \\
(\% \circ)\end{array}$ & $\begin{array}{l}\text { Sea-air flux } \\
\left(\mu \mathrm{mol} \mathrm{m} \mathrm{m}^{-2} \mathrm{~d}^{-1}\right)\end{array}$ & $\begin{array}{l}\text { Sea-air flux } \delta^{13} \mathrm{C}_{\mathrm{CH}_{4}} \\
\text { (\%) }\end{array}$ & Reference \\
\hline $\begin{array}{l}\text { Arabian Sea } \\
\text { Caribbean Sea } \\
\text { Subtropical Atlantic } \\
\text { Atlantic Ocean }\left(50^{\circ} \mathrm{N}-35^{\circ} \mathrm{S}\right) \\
\text { Open ocean } \\
\text { Eastern tropical North Pacific } \\
\text { North Atlantic }\end{array}$ & $\begin{array}{l}2.30 \text { (2.26 to } 3.96) \\
2.7^{\text {a }}(2.4 \text { to } 3.0)\end{array}$ & $\begin{array}{l}-40.7(-46.9 \text { to }-41.5) \\
-46.1^{\mathrm{a}}(-46.6 \text { to }-45.5)\end{array}$ & $\begin{array}{l}9.25^{\mathrm{a}}(4.6 \text { to } 13.9) \\
0.23(-) \\
0.08(-) \\
0.23 \text { (0.09 to } 4.65) \\
2.76^{\mathrm{a}}(2.05 \text { to } 3.46) \\
1.88^{\mathrm{a}}(0.77 \text { to } 3.0) \\
\left.3.0^{\mathrm{a}} \text { (1.6 to } 4.4\right)\end{array}$ & $\begin{array}{l}-42.6^{a}(-48.2 \text { to }-37.0) \\
-44.0^{a}(-45.0 \text { to }-43.0)\end{array}$ & $\begin{array}{l}\text { Owens et al., } 1991 \\
\text { Ward et al., } 1987 \\
\text { Scranton and Brewer, } 1978 \\
\text { Conrad and Seiler, } 1988 \\
\text { Ehhalt, } 1974 \\
\text { Sansone et al., } 2001 \\
\text { Holmes et al., } 2000\end{array}$ \\
\hline \multicolumn{6}{|l|}{ Southern Ocean } \\
\hline $\begin{array}{l}\text { Drake Passage } \\
\text { South Shetland Islands } \\
\text { Bransfield Strait }\end{array}$ & $\begin{array}{l}2.69(2.22 \text { to } 3.09) \\
3.80(2.80 \text { to } 7.09) \\
3.18(2.71 \text { to } 3.97)\end{array}$ & & $\begin{array}{l}-0.35(-0.77 \text { to } 0.01) \\
1.05(-0.41 \text { to } 5.86) \\
0.15(-0.54 \text { to } 1.30)\end{array}$ & & $\begin{array}{l}\text { Tilbrook and Karl, } 1994 \\
\text { Tilbrook and Karl, } 1994 \\
\text { Tilbrook and Karl, } 1994\end{array}$ \\
\hline $\begin{array}{l}\text { Weddell Sea } \\
\text { Front at } 173 \sim 177^{\circ} \mathrm{E} \\
\text { Front at } 140^{\circ} \mathrm{E}\end{array}$ & $\begin{array}{l}2.86^{\mathrm{b}} \\
2.72(2.10 \text { to } 3.04) \\
3.16(3.07 \text { to } 3.22)\end{array}$ & $\begin{array}{l}-46.0(-) \\
-46.6(-46.7 \text { to }-46.4)\end{array}$ & $\begin{array}{l}-0.47(-) \\
0.32(-0.09 \text { to } 0.74)\end{array}$ & $\begin{array}{l}-54.1^{\mathrm{b}}(-55.8 \text { to }-52.5) \\
-42.7(-47.9 \text { to }-34.8)\end{array}$ & $\begin{array}{l}\text { Heeschen et al., } 2004 \\
\text { Swinnerton and Lamontagne, } 1974 \\
\text { This study }\end{array}$ \\
\hline
\end{tabular}

${ }^{a}$ average value from the range ${ }^{b}$ calculated value from the raw data.

\section{N. Boontanon et al.}

Title Page

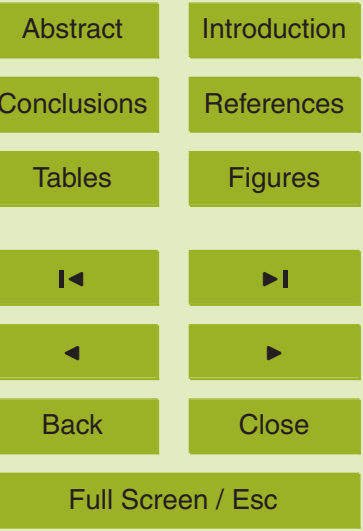

Printer-friendly Version

Interactive Discussion 


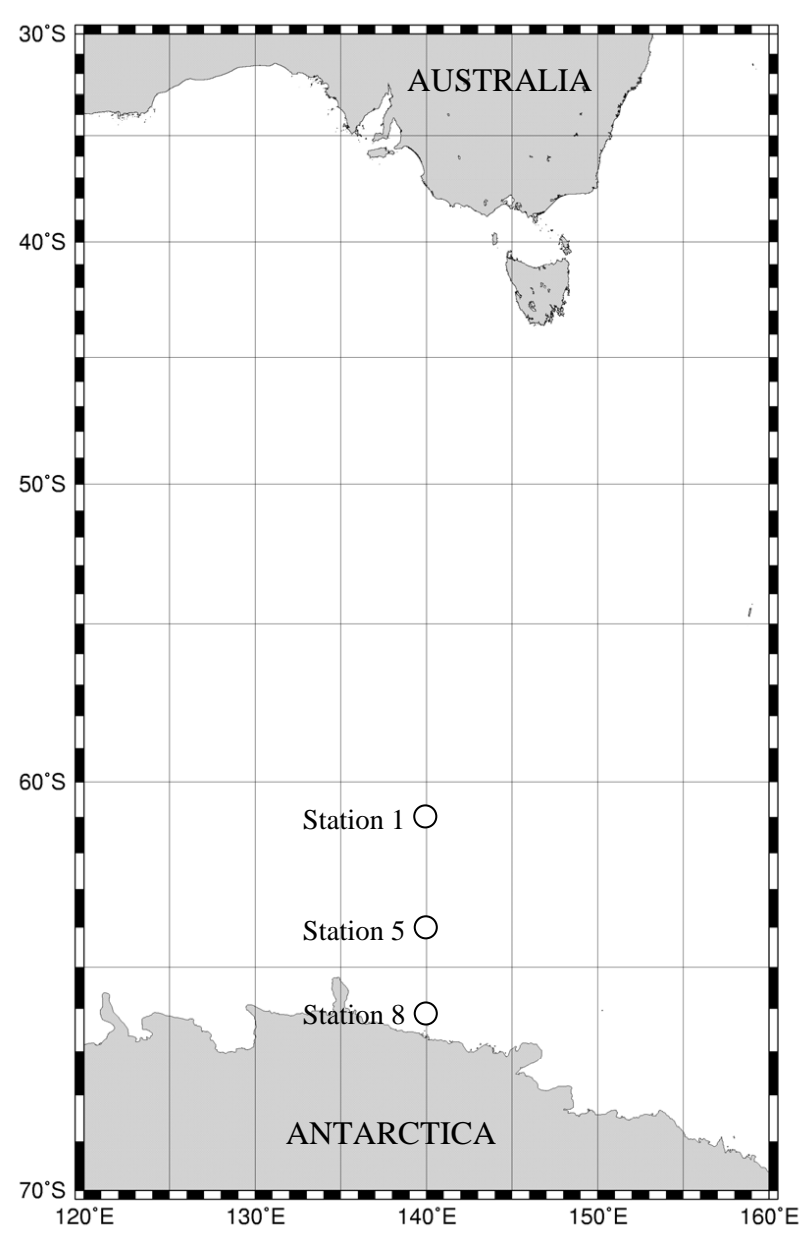

\section{BGD}

7, 7207-7225, 2010

Methane production and consumption in the Southern Ocean

N. Boontanon et al.

Title Page

Abstract

Conclusions

Tables

I

4

Back
Introduction

References

Figures

$>$ I

$>$

Close

\section{Full Screen / Esc}

Printer-friendly Version

Interactive Discussion

Fig. 1. Location of sampling stations during the JARE-43 Marine Science Cruise on the $\mathrm{R} / \mathrm{V}$ Tangaroa. 
BGD

$7,7207-7225,2010$

\section{Methane production} and consumption in the Southern Ocean
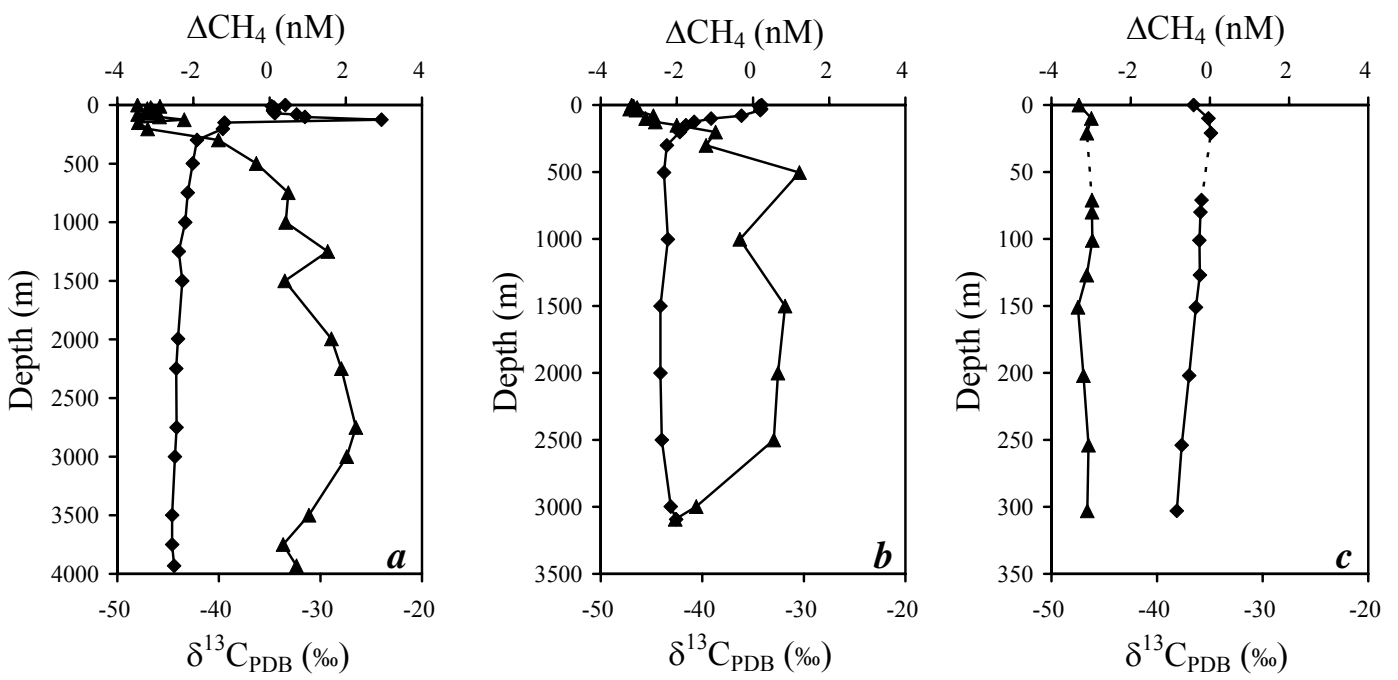

Fig. 2. Depth profiles of $\Delta \mathrm{CH}_{4}$ (diamonds) and $\delta{ }^{13} \mathrm{C}_{\mathrm{CH}_{4}}$ (triangles) at (a) station 1, (b) station 5 , and (c) station 8 in the Southern Ocean during the austral summer.
N. Boontanon et al.

\section{Title Page}

\section{Abstract}

Introduction

Conclusions

References

Tables

Figures

14

4

Back

Close

\section{Full Screen / Esc}

Printer-friendly Version 